
\title{
ПРОВЕДЕННЯ ОБ’ЄКТИВНОГО СТРУКТУРОВАНОГО КЛІНІЧНОГО ІСПИТУ
}

\author{
N. I. Korylchuk, O. O. Vorontsov, O. R. Yasniy \\ I. Horbachevsky Ternopil National Medical University \\ TAKING OF OBJECTIVE STRUCTURED CLINICAL EXAMINATION
}

\begin{abstract}
Анотація. У статті проаналізовано проведення викладачами старших курсів об'єктивного структурованого клінічного іспиту (OCKI) на III курсі. Наведено науково-методичні погляди на проведення ОСКІ в різних університетах і країнах, показано можливість оцінити не лише теоретичні, а й практичні знання студента (як функціональні, так і комунікативні). Проведено детальний аналіз роботи на двох станціях (фізикальне обстеження серцево-судинної системи; розпитування пацієнта із захворюванням внутрішніх органів) із використанням різних чек-листів, що дало можливість виявити рівень теоретично-практичних знань студентів. У статті наведено приклади детального аналізу комунікативних компетентностей студентів-медиків, що складали OCKI. Окремі акценти вказують на комунікацію як основу роботи майбутнього лікаря, яка є набутою й потребує постійного розвитку, тренувань та вдосконалень, як і всі теоретично-практичні знання в медицині.

Співпраця в ОСКІ дозволила краще зрозуміти методику викладання студентам-медикам на молодших курсах та вдосконалити викладання студентам-старшокурсникам. У щоденній роботі зі студентами важливими є акценти не лише на теоретично-практичних нюансах медицини в цілому, а й на комунікативних навичках, словниковому запасі, формулюванні запитань і речень тощо. В подальшому було б доцільним проведення постійних додаткових факультативів, лекцій, онлайн-навчання з комунікації, психології, професійного мовлення фахівців-медиків, метою яких має бути підготовка спеціалістів високого рівня, які могли б вільно орієнтуватися в різноманітних медико-комунікативних ситуаціях та уникнути емоційного вигорання.
\end{abstract}

Ключові слова: ОСКІ; освітній процес; комунікативна компетентність.

Abstract. The paper deals with the taking of objective structured clinical examination (OSCE) for the students of third year of studies. There were presented the scientific and methodical views on the carrying out of OSCE in various universities and countries, where there was shown the possibility to estimate not only the theoretical knowledge of student, but also the practical ones (the functional as well as the communicative). There was performed the detailed analysis of work at two stations (the physical diagnostics of cardio-vascular system; the questioning of patient with the diseases of internal organs of the body) using different check-lists that enables to observe the theoretical and practical knowledge of students. There were given the examples of thorough analysis of communicative competences of medical students that passed OSCE. Some accents were made on the communication as the foundation of work of the future doctor, since the ability of effective communication is acquired and demands constant development, training and improvement as well as general theoretical and practical knowledge in medicine.

The cooperation at OSCE allows understanding better the teaching methodology for medical students on the initial courses and improving the teaching for the undergraduate students. While working with the students every day, it is necessary to stress not only on the theoretical and practical nuances of the medicine in general, but also on the communicative skills, on the vocabulary, on the formulation of questions and sentences, and so on. In the future, it would be appropriate to organize the additional elective courses, lectures, online trainings on communication, psychology, professional language of medical specialists in order to form the specialists of high level that can orientate in various medical and communicative situations and also to avoid the emotional burnout of medical student, and the subsequent doctor.

Key words: OSCE; educational process; communicative competence.

(c) Н. І. Корильчук, О. О. Воронцов, О. Р. Ясній 
Вступ. Об’єктивний структурований клінічний іспит (OCKI) (Objective Structured Clinical Examination (OSCE)) - сучасний метод оцінки практичних знань та вмінь студентів, що призначений для перевірки набуття ними клінічної майстерності та компетентностей, які неможливо оцінити за допомогою іспитів традиційної форми $[6,11]$.

OCKI вперше був описаний Гарденом у 1975 р. як альтернатива існуючим методам оцінки клінічної майстерності [9]. Він був створений для підвищення достовірності оцінки результативності, яку раніше оцінювали за допомогою тривалих і коротких обстежень. Найпопулярнішим цей іспит $є$ у Великобританії [8, 9].

Запровадження ОСКІ в існуючу програму оцінювання є досить складним процесом, який вимагає досвіду від викладачів і значного обсягу теоретичних та практичних знань від студентів [4, 9, 12].

На сьогодні існує низка науково-методичних доробків [4, 7-9], які розкривають суть проведення OCKI, їх видозмінювання, удосконалення, осучаснення, оновлення тощо. Проведення ОСКІ - вимога медичного навчання сьогодення. Ця методика, на відміну від традиційних методів оцінювання знань, дозволяє оцінити та продемонструвати, що студенти «можуть зробити», а не те, що вони «знають» $[7,8]$. Професія лікаря належить до професій типу «людина - людина», тому професіоналізм фахівця залежить насамперед від його комунікативних якостей, стилю спілкування, від сили впливу на поведінку інших людей та інтегральної чутливості до об'єкта, процесу й результату професійної діяльності [5]. Науковці наголошують [3, 5, 6, 10], що у процесі комунікативної діяльності лікар виконує лікувальну, діагностичну, психологічну, посередницьку та інші функції, розв'язуючи одночасно низку професійних завдань, таких, як: установлення контакту з пацієнтом; отримання й передача інформації, зчитування й передача емоційного стану; вплив на поведінку та хід думок пацієнта тощо. Якщо лікар вміло організує професійне спілкування, то в пацієнта активізуються додаткові психологічні сили, які можуть сприяти швидкому одужанню. При цьому лікар виконує різні ролі [5, 6, 10], такі, як: лікар-дослідник, лікар-психотерапевт, лікар-співрозмовник, лікар-колега, лікарпорадник. Кожна з професійних ситуацій, зумовлена однією із названих ролей, передбачає володіння словом, яке є не лише інструментом спілкування, а часто й чудодійними ліками, особливо якщо його вчасно сказано та вдало підібрано. Натомість недо- речне й невдале слово може призвести до негативних наслідків.

Мета статті - аналіз проведення ОСКІ викладачами старших курсів на III курсі, який дозволить краще зрозуміти методику викладання студентаммедикам на молодших курсах та вдосконалити викладання студентам-старшокурсникам.

Теоретична частина. Для досягнення мети використано теоретичні та емпіричні методи дослідження (спостереження, порівняння, моніторинг), аналіз літератури, аналіз чек-листів ОСКІ для студентів III курсу.

Оцінювання студентів III курсу за методикою стандартизованого клінічного іспиту в ТНМУ імені I. Я. Горбачевського відбувалося з залученням до іспитів викладачів кафедри первинної медико-санітарної допомоги та загальної практики - сімейної медицини. Цей досвід дав достатньо підстав для міркувань, які, на нашу думку, заслуговують на більш широке обговорення.

Варто відзначити добру організацію іспиту, який враховує всі складові, необхідні для демонстрації студентами різних професійних навичок у формі, яка в навчальному процесі $€$ найвищою й має назву «ділова гра».

Дванадцять екзаменаційних завдань виконувалися в 12-ти кабінетах - «станціях», з відповідною нумерацією. Кожен студент, згідно з особистою маршрутною картою, мав змогу сумарно заробити відмінну оцінку (12 балів) - по одному балу на кожній станції. Викладачі нашої кафедри забезпечували роботу двох станцій - «Станція 1» (фізикальне обстеження серцево-судинної системи) та «Станція 11» (розпитування пацієнта із захворюванням внутрішніх органів).

На «Станції 1» оцінювали ряд компетентностей по 4 чек-листах. А саме: визначення меж відносної тупості серця та судинного пучка методом перкусії; визначення меж абсолютної тупості; вимірювання артеріального тиску на обох руках за методом Короткова; реєстрація електрокардіограми.

На «Станції 11» проводили збір скарг та анамнезу за чотирма основними системами: серцевосудинною, дихальною, сечовидільною і шлунковокишкового тракту. Опитування проводили згідно з розробленими чек-листами, які включали різні моменти пропедевтики внутрішніх захворювань. Дуже важливо, що в чек-листах були запропоновані наступні кроки алгоритму дій студента після отримання даних від хворого: вміння підсумову- 
вати отримані результати і визначати подальшу діагностичну та лікувальну тактику.

Викладачі кафедри проводили консультації з працівниками ВН3, що готували ОСKI, під час яких давали вичерпні відповіді щодо технічних моментів проведення іспиту, орієнтовних алгоритмів вирішення задач, клінічних сценаріїв, розподілу балів та їх підсумовування. Чек-лист по кожній зі станцій обирали безпосередньо перед іспитом для унеможливлення витоку інформації. Після закінчення іспиту з кожної станції вилучали екзаменаційний лист з балами і опрацьовували його, підраховуючи кількість балів по всіх станціях. Атмосфера під час іспиту була робочою, студенти були позитивно налаштовані і максимально мобілізовані на успішне завершення випробування.

Спільним для кожного екзаменаційного завдання обох станцій була необхідність демонструвати власні комунікативні навички першого контакту 3 пацієнтом, навіть коли його роль грав манекен (волонтер).

При ознайомленні з різними компетентностями, готуючись до перевірки ОСКІ по «Станції 1», ми звернули увагу, що комунікативним навичкам відводиться 0,1 бала з 1 можливого. При виконанні завдань станції ймовірність втратити по 0,02 бали (5 комунікативних навичок по 0,02 в сумі становили 0,1 бала) через невміння спілкуватися з пацієнтом здавалася нереальною. Проте ми помилилися... Більшість студентів губилися при демонстрації комунікативних навичок, а саме: забували привітатися і представитися, пояснити мету спілкування, отримати згоду пацієнта, проводити словесний котроль самопочуття під час обстеження тощо. Здавалося, що студенти якнайшвидше хочуть виконати фізикальне обстеження пацієнта-волонтера і перейти на іншу станцію для складання OCKI.

Наприклад, простежувалося наступне - студент наклав електроди пацієнту-волонтеру, зареєстрував ЕКГ, не спілкувався з пацієнтом ні до, ні після обстеження (часто й не зняв електроди), залишив плівку пацієнта в ЕКГ-апараті (часто без даних пацієнта), вийшов зі станції. При цьому виконання фізикального обстеження (запис ЕКГ) для студентів виявилося найпростішим, усі майже без помилок накладали електроди, працювали з ЕКГ-апаратом тощо. Траплялося й таке, що студент настільки заглиблювався у виконання перкусії меж серця, що зовсім забував про комунікацію.

Найбільше балів втрачали студенти, яким дістався чек-лист із вимірюванням АТ. Банальне, здава- лося б, вимірювання артеріального тиску на обох руках за методом Короткова (за одним з чек-листів) чомусь виявилося для студентів (україномовних та іноземців) найскладнішим у всіх відношеннях. До прикладу, часто студенти забували уточнити робочий АТ пацієнта, неправильно накладали манжетку, забували вимірювати тиск на обох руках, наповнювали манжетку на 80-100 мм рт. ст. більше потрібних цифр тощо. Ми, викладачі, що працюють зі студентами старших курсів, намагаючись зрозуміти таку ситуацію, можемо пояснити їі відсутністю стажу користування тонометрами і, як наслідок, відсутністю автоматизму в проведенні вказаного обстеження. Вже після ОСКІ, спілкуючись зі студентами в позаекзаменаційній обстановці, ми з'ясували, що багато хто в домашніх умовах користується електронними тонометрами (напівмеханіка, напульсники тощо). Студенти, які мають родичів, котрим доводиться вимірювати АТ, краще володіють методикою (тобто спрацьовує автоматизм). Знання теорії вимірювання АТ без постійної практики виявилося малоефективним.

На «Станції 1» ми спостерігали цікаву тенденцію - україномовні студенти добре виконували фізикальні обстеження, проте погано володіли (дехто майже не володів) комунікативними навичками. Натомість студенти-іноземці показували набагато кращий результат комунікативних навичок: демонстрували привітний вираз обличчя, віталися, усміхалися, чітко представлялися, пояснювали мету спілкування, перепитували під час обстеження про самопочуття обстежуваного, дякували, прощалися тощо. Інколи вони настільки вдавалися до комунікації, що просто не встигали завершити фізикальне обстеження й теж втрачали бали.

На «Станції 11» проводили оцінювання серцевосудинної системи, яке полягало в деталізації скарг і анамнезу хворого з підозрою на інфаркт міокарда. Стандартизовані пацієнти мали чіткі інструкції, відповідно до яких дуже чітко і лаконічно відповідали лише на коректно поставлене запитання. Це вимагало від студентів логічного мислення і знання алгоритму збору скарг та анамнезу у пацієнта з гострим коронарним синдромом, а саме: 3’ясування місця локалізації болю, його іррадіації, тривалості, характеру та інтенсивності. Опитування щодо сечовидільної системи було націлене на виявлення умінь студентів визначати особливості больового синдрому у пацієнтів із захворюваннями сечового міхура і нирок. Запитання стосувалися різних аспектів дизуричного та інтоксикаційного 
синдромів. Чек-листи іншого спрямування стосувалися опитування хворого з патологією ШКТ. У них більше уваги приділялося виявленню факторів ризику виникнення захворювань шлунка та печінки. Зокрема, студент повинен був згадати про чинники, які сприяють виникненню гепатитів C, B, ВІЛ-інфекції тощо. Важливе значення надавалося і вмінню розпитувати про характеристику больового синдрому, дотримання пацієнтом раціонального харчування, шкідливі звички. Опитування хворого 3 патологією дихальної системи мало на меті оцінити знання студентів з питань діагностики ХОЗЛ шляхом деталізації скарг та анамнезу стандартизованого пацієнта. Велика увага була приділена вмінню проаналізувати результати клініко-інструментальних методів обстеження, на які хворий опирався у своїх відповідях на запитання.

Викладач на цій станції мав оцінити алгоритми дій студента у вибраній клінічній ситуації. При цьому саме на цій станції студент мав продемонструвати активні комунікативні навички, а саме 3 привітним виразом обличчя й усмішкою привітатися, представитися, вказати рівень компетенції (студент якого курсу), пояснити мету спілкування, отримати згоду на це; запитати, як до пацієнта можна звертатися; уточнити його паспортні дані; зібрати основні скарги; розпитати про деталі кожної з них, про можливі супутні скарги, історію його захворювання, розвиток симптомів у динаміці (посилення, зникнення, поява нових симптомів); попередні обстеження та їх результати; попереднє лікування та його ефективність; дати відповідь на питання пацієнта тощо. Проте в частині роботи «Опитування хворого» помітною виявилася неприємна тенденція. Інформація, яку «хворий», за сценарієм ділової гри мав надавати лише у відповідь на уточнювальні запитання (деталізація скарг тощо), часто залишалася невикористаною. Інколи, як і в реальному житті, хворий, сподіваючись на більш швидку реакцію лікаря, починав самостійно «вдаватися в деталі». Така ситуація виникала після несподіваної заяви студента про завершення опитування. Зрозуміло, що оцінка втрачала частину балів (0,05, 0,1 або й більше).

Про які комунікативні чи професійні навички можна говорити, коли освіта та професія хворого залишалися невідомими? Скільки вірогідних несприятливих або шкідливих факторів залишаються поза увагою фахівця? Яким буде прогноз передінфарктного стану чи патології легень, коли провокувальні чинники не виявлені і продовжують діяти? Як формулювати, наскільки спрощувати запитання? Наприклад: «У вас продуктивний кашель?», «Чи не маєте розладів ШКТ?»

Складалося враження, що студенти бачать перед собою не хворого як особистість, а лише певний симптомокомплекс. До цієї думки ми схилялися, коли дехто зі студентів демонстрував, що не вміє й слухати відповіді на власні запитання.

Наприклад:

- У вас є підвищення температури?

- Так.

- Добре. А ще щось турбує?

- Кашель.

- Добре. А болі відчуваєте?

- Так.

- Добре...

Більшість відповідей хворого мала б породжувати послідовні додаткові логічні запитання лікаря, що й складає зміст професійного спілкування. В прикладі, що наведено, не було 3’ясовано, наскільки висока температура, скільки часу триває тощо. Окрім того, слово «Добре» з вуст студентамедика виглядало недоцільним. Виникало бажання спитати: «Добре, що болить?; Добре, що температура?», чи «Добре, що болить і температура у Вас, а не у мене?».

Ми, викладачі кафедри первинної медико-санітарної допомоги та загальної практики - сімейної медицини, у своїй повсякденній роботі оцінюємо рівень знань та вмінь студентів VI курсу, а в цій ситуації фактично спостерігали за результатами зусиль своїх колег на попередньому етапі навчання. Цей досвід дав нам поштовх до вдосконалення занять зі старшокурсниками, показав, на що потрібно звернути увагу, що ще запропонувати, впровадити у навчальний процес, на чому зробити акценти. Це спонукало нас до внесення корективів у щоденні навчальні плани (необхідність більше уваги приділяти комунікації) і підходи до перевірки і контролю знань.

За педагогічним визначенням, навички - це прості професійні дії, які доведено до автоматизму шляхом багаторазового повторення. Отже, ми розуміємо, що після трьох років навчання студенти перебувають лише в процесі свого самовдосконалення і демонструють інколи далеко не кращі результати. Нам є ще над чим працювати і ми знаємо, як сприяти покращенню підготовки фахівців. Самі ж студенти, незважаючи на стрес, пов’язаний 3 іспитом, теж сприймали його позитивно, охоче аналізували свої помилки, прорахунки, інколи більше обумовлені поспіхом, ніж незнаням. Це свідчить про високий навчальний характер подібних форм перевірки знань. 
На завершення нагадаємо афоризми, авторство яких приписують Гіппократу [1, 2]: «Всяка справа вдосконалюється оволодінням техніки»; «Всякий навик досягається вправою»; «Лікарське мистецтво може бути надбано тільки протягом дуже довгого часу, і тільки тоді воно може принести користь людям».

Висновки та перспективи подальших досліджень. Ми отримали досвід проведення ОСКI, i, незважаючи на складність, сприймаємо його як позитивний. Проведення ОCKI $є$ цікавим та динамічним, дозволяє оцінити не лише теоретичні знання студента, а й практичні, як функціональні, так і комунікативні.

У щоденній рутинній роботі викладача й спілкуванні зі студентами-медиками різних курсів потрібно робити важливий акцент не лише на теоретично-практичних нюансах медицини в цілому, а

\section{Список літератури}

1. Афоризмы великих врачей: Гиппократ, Гелен, Авицена, Арнольд из Виллановы, Парацельс / [сост. В. П. Бутромеев, В. В. Бутромеев]. - М. : Просвещение, 2017. - 304 с.

2. Воронцов О. О. Використання афоризмів медичного спрямування у викладанні загальної практики - сімейної медицини на додипломному етапі вищої медичної освіти / О. О. Воронцов, Л. С. Бабінець // Сімейна медицина. - 2018. - № 1 (75). - С. 51-54.

3. Воронцов О. О. Досвід минулого у формуванні комунікативних навичок майбутнього лікаря: «Знаючи минуле, лікар повинен передбачати майбутнє» / О. О. Воронцов, Л. С. Бабінець // Сімейна медицина. - 2019. № 2 (82). - С. 11-13.

4. Впровадження об’єктивного структурованого клінічного іспиту для проміжної атестації лікарів-інтернів I року навчання за фахом «Анестезіологія та інтенсивна терапія» / О. М. Клигуненко, В. В. Єхалов, В. А. Седінкін, В. В. Халимончик // Південноукраїнський медичний науковий журнал. - 2016. - № 14 (14). - С. 54-57.

5. Климов Е. А. Психология профессионала / Е. А. Климов. - М. ; Воронеж, 1996.

6. Корильчук Н. І. Комунікативність майбутнього лікаря / Н. І. Корильчук, Н. Є. Боцюк, В. М. Творко // Українська професійна мова: історія і сучасність : зб. матеріалів II регіональної наук.-практ. конф. - 2016. - С. 6-8.

\section{References}

1. Butromeev, V.P., \& Butromeev, V.V. (Comps.). (2017). Aforizmy velikikh vrachey: Gippikrat, Gelen, Avitsena, Arnold iz Villanovy, Paratsels [Aphorisms of the great doctors: Hippocrates, Galen, Avicenna, Arnold from Villanova, Paracelsus]. Moscow: Prosveshchenie [in Russian]. й на комунікативних навичках, словниковому запасі, формулюванні речень тощо. Доцільним було б впровадження додаткових факультативів, лекцій, онлайн-навчань 3 питань комунікації, психології тощо. Це допоможе отримати в майбутньому професіоналів високого рівня та, водночас, уникнути емоційного вигорання студентів-медиків та лікарів.

Представлені результати досліджень є початковою ланкою визначення особливостей проведення OCKI з погляду викладачів старших курсів і потребують подальшого вивчення. Перспективою подальших досліджень є розроблення шляхів активного впливу на комунікацію студентів, реалізацію визначених педагогічних умов та створення, апробацію, перевірку на старших курсах, ефективності проведення OCKI на молодших курсах для формування високої культури професійного розвитку майбутніх лікарів.

Конфлікт інтересів: відсутній

7. Оюунгоо Б. Формативная оценка клинических навыков студентов в OSCE / Б. Оюунгоо, Д. Цэрэндагва, Б. Солонго // Сибирский медицинский журнал. - 2010. № 7. - С.12-13.

8. Пилипенко М. М. Перший досвід впровадження Британського варіанта екзамену за системою OSCE наприкінці дворічної інтернатури / М. М. Пилипенко, I. Рибінкіна, I. П. Шлапак // Біль, знеболення та інтенсивна терапія. - 2014. - № 3. - С. 5-14.

9. Структурований клінічний іспит з анестезіології у Великій Британії: досвід впровадження в Україні / М. М. Пилипенко, І. Рибінкіна, М. В. Бондар, І. П. Шлапак // Медицина неотложных состояний. - 2015. - № 1. 10. Do certain personality types have a particular communication style? / J. R. Frank, L. Snell, J. Sherbino, R. C. Emanuel // Intarnational Jounal of Social Science and Humanities. - 2013. - No. 2 (1). Publisher Full Text.

11. Kilminster S. Standard setting for OSCEs: trial of borderline approach / S. Kilminster, T. Roberts // Adv. Health Sci. Educ. Theory Pract. - 2004. - No. 9 (3). - P. 201-209. 12. Mukerji G. Objective Structured Clinical Examination (OSCE) Rating Scales. Communicating with patients and families about unnecessary tests and treatments / G. Mukerji // The Royal Collage of Physitians and Surgions of Canada; 2017.

2. Vorontsov, O.O., \& Babinets, L.S. (2018). Vykorystannia aforyzmiv medychnoho spriamuvannia u vykladanni zahalnoi praktyky - simeinoi medytsyny na dodyplomnomu etapi vyshchoi medychnoi osvity [Use of aphorisms of medical direction in teaching general practice - family 
medicine in the undergraduate stage of higher medical education]. Simeina medytsyna - Family Medicine, 1 (75), 51-54 [in Ukrainian].

3. Vorontsov, O.O., \& Babinets, L.S. (2019). Dosvid mynuloho u formuvanni komunikatyvnykh navychok maibutnoho likaria: "Znaiuchy mynule, likar povynen peredbachaty maibutnie” [Past experience in shaping the communication skills of the future doctor: "Knowing the past, the doctor must anticipate the future”]. Simeina medytsyna - Family Medicine, 2 (82), 11-13 [in Ukrainian].

4. Klyhunenko, O.M., Yekhalov, V.V., Sedinkin, V.A., \& Khalymonchyk, V.V. (2016). Vprovadzhennia obiektyvnoho strukturovanoho klinichnoho ispytu dlia promizhnoi atestatsii likariv interniv i roku navchannia za fakhom "Anesteziolohiia ta intensyvna terapiia” [Implementation of an objective structured clinical examination for intermediate certification of interns of the first year of study in the specialty "Anesthesiology and intensive care”]. Pivdennoukrain. Med. zhurn. - South. Ukrain. Med. Scient. Journ., 14 (14), 54-57 [in Ukrainian].

5. Klymov, E.A. (1996). Psikhologiya professionalla [Psychology of a Professional]. Moscow-Voronezh [in Russian].

6. Korylchuk, N.I., Botsiuk, N.Ye., \& Tvorko, V.M. (2016). Komunikatyvnist maibutnoho likaria [Communicative skills of future doctor]. Proceedings of the Second Regional Scientific and Practical Conference: "Ukrainian Professional Language: History and Modernity” (pp.6-8) [in Ukrainian].
7. Oiuunhuu, B., Tserendagva, D., \& Solonho, B. (2010). Formativnaya otsenka klinicheskikh navykov studentov $\mathrm{v}$ OSCE [Formative assessment of the clinical skills of students at the OSCE]. Sibir. Med. zhurn. - Siberian Medical Journal, 7, 12-13 [in Russian].

8. Pylypenko, M.M., Rybinkina, I., \& Shlapak, I.P. (2014). Pershyi dosvid vprovadzennia Brytanskoho variant ekzamenu za systemoiu OSCE naprykintsi dvorichnoi internatury [The first experience of implementing the British OSCE exam at the end of a two-year internship]. Bil, znebolennia ta intensyvna terapiia - Pain, Anesthesia and Intensive Care, 3, 5-14 [in Ukrainian].

9. Pylypenko, M.M., Rybinkina, I., Bondar, M.V., \& Shlapak, I.P. (2015). Strukturovanyi klinichnyi ispyt z anesteziolohii u Velykii Brytanii: dosvid vprovadzennia v Ukraini [Structuring clinical examination with anesthesiology in Great Britain: experience of implementation in Ukraine]. Meditsina neotlozhnykh sostoyaniy - Medicine of Emergency, 1, 178-184 [in Ukrainian].

10. Frank, J.R., Snell, L., \& Sherbino, J., \& Emanuel, R.C. (2013). Do certain personality types have a particular communication style? Intarnational Jounal of Social Science and Humanities, 2 (1).

11. Kilminster, S., \& Roberts, T. (2004). Standard setting for OSCEs: trial of borderline approach. Adv. Health Sci. Educ. Theory Pract., 9 (3), 201-209.

12. Mukerji, G. (2017). Objective Structured Clinical Examination (OSCE) Rating Scales. Communicating with patients and families about unnecessary tests and treatments. The Royal Collage of Physitians and Surgions of Canada. 